\title{
Morphological and Biometrical Characteristics on Otolith of Barbus tauricus Kessler, 1877 on Light and Scanning Electron Microscope
}

\author{
Características Morfológicas y Biométricas de los Otolitos de Barbus tauricus \\ Kessler, 1877 bajo Microscopio de Luz y Electrónico de Barrido
}

\author{
Seda Kontas* \& Derya Bostanci**
}

KONTAS, S. \& BOSTANCI, D. Morphological and biometrical characteristics on otolith of Barbus tauricus Kessler, 1877 on light and scanning electron microscope. Int. J. Morphol., 33(4):1380-1385, 2015.

SUMMARY: The otolith morphology, biometry and the relationship between the otolith size and fish length were examined. The weight, length, width, area and perimeter were recorded for each pair of otoliths. The values of form factor (FF), roundness (RD), aspect ratio (AR), circularity (C), rectangularity (R) and elipticity (E) were calculated and the relationships between otolith length (OL) and shape indices were showed with graphics. According to paired t-test results, difference between right and left otoliths was important statistically $(\mathrm{P}<0.05)$, except otolith length. It is the first time, the difference of otolith variables were observed not only right and left pairs but also females and males of fish a member of Cyprinidae. While the otolith weight had the lowest coefficient of determination $\left(\mathrm{r}^{2}\right)$ such as $0.69 ; 0.59 ; 0.65$, otolith length had the highest $0.80 ; 0.81 ; 0.80$, for female, male and all specimens, respectively. In addition, SEM images were firstly shown for otoliths of $B$. tauricus to determine the otolith morphology.

KEY WORDS: Otolith dimensions; Asteriscus; Shape indices; Otolith SEM.

\section{INTRODUCTION}

The otoliths are hard calcified structures located in the inner ear of all teleost fishes. There are three pairs of otoliths named as sagitta, asteriscus and lapillus (Das, 1994). Otoliths show the differences in size and shape. The sagittae are the biggest pair of otoliths, the lapillii are the smallest in most bony fishes; however, in the members of Cypriniformes and Siluriformes the asteriscii are the largest otoliths, and the sagittae are the smallest (Assis, 2003; Campana, 2004). For the ichthyologist, the otolith is one of the most important tools for understanding the lives of fishes and fish populations (Chilton \& Beamish, 1982). Although the otoliths can be used for different studies such as age determination, estimation of growth parameters, and population dynamics, knowledge of otolith morphology is still very limited. The size, shape, and otolith characteristics vary among from species, and morphological descriptions of otoliths provide information that complements the characterization of some ichthyological taxa (Tuset $e t$ al., 2008). Thus, biologists, including as taxonomists and archaeologists, often rely on the shapes and sizes of preserved or undigested otoliths and some diagnostic bones to reconstruct the species and size composition of diets of piscivorous fauna (Hajkova et al., 2003; Britton \& Shepherd, 2005).

By using the relationship between fish length and otolith biometry, it is possible to determine fish length from otolith size or vice versa. This information especially is very useful for analysis of digestive tract contents of predator animals, for it is possible to estimate size and species of prey fishes from otoliths, which are found in digestive tracts such as carnivore fishes, aquatic birds, reptiles and mammals.

The studies of otolith morphology and biometry have recently become important, with the development of image analysis systems. However, these studies on the Turkish freshwater ichthyofauna are quite limited in number. Available literature has revealed the lack of otolith biometryfish length relationship studies on B. tauricus in Turkey. Thus, the purpose of this study was to provide seminal documentation of measurements of otoliths of this species, and relate these measurements to fish length.

\footnotetext{
* Department of Fisheries Technology Engineering, Ordu University, Ordu, Turkey.

** Department of Biology, Ordu University, Ordu, Turkey.
} 


\section{MATERIAL AND METHOD}

A total of 350 B. tauricus (159 females, 159 males and 32 undetermined sexes) were caught by using shocker and gillnets through June 2010-October 2011 from the lower Melet River, Turkey. Each fish was cleaned from external materials and weighted by Precisa $3100 \mathrm{C}$ brand analytical balance with $\pm 1 \mathrm{~g}$ sensitiveness, fork length (FL) was measured to the nearest $1 \mathrm{~mm}$ by digital caliper.

Asteriscus otolith pairs were removed, cleaned and stored dry before examination. Undamaged and cleaned otolith pairs were weighed to the nearest 0.0001 $\mathrm{g}$ on Precisa XB220A brand balance. Each otolith pairs were photographed and otolith length $(\mathrm{OL}, \mathrm{mm})$, otolith width $(\mathrm{OW}, \mathrm{mm})$, otolith area $\left(\mathrm{A}, \mathrm{mm}^{2}\right)$ and otolith perimeter $(\mathrm{P}, \mathrm{mm})$ were measured by using Leica S8APO brand light microscope and computer-connected camera system. 'Leica Application Suit' software was used for all measurements. Otolith length was measured from anterior to posterior axis and otolith width was from dorsal to ventral edge through the otolith focus.

The otolith pairs were attached on a stub by using double-sided carbon tape in order to be easily scanned. The immobilized otoliths, on stub, were covered with 13.5 $\mathrm{nm}$ gold. Asteriscus otoliths were analyzed by using SEM (JMS-6060LV brand microscope) at 5.0 KV in a biology laboratory at Gazi University.

The t-test was applied in order to determine the differences between otoliths of females and males. The differences between right and left otoliths were tested by using a paired t-test; right otoliths were used for calculations. All calculations were performed with MINITAB 16.0 software package. The shape indices were calculated using the formulas below according to Tuset $e t$ al. (2003) and Lord et al. (2012) to describe shape of otoliths.

$$
\begin{gathered}
\mathrm{FF}=4 \pi \mathrm{A} \mathrm{P}^{-2} \quad \mathrm{RD}=4 \mathrm{~A}\left(\pi \mathrm{OL}^{2}\right)^{-1} \quad \mathrm{AR}=\mathrm{OL} \mathrm{OW}^{-1} \\
\mathrm{C}=\mathrm{P}^{2} \mathrm{~A}^{-1} \quad \mathrm{R}=\mathrm{A}(\mathrm{OL} \mathrm{OW})^{-1} \quad \mathrm{E}=(\mathrm{OL}-\mathrm{OW})(\mathrm{OL}+\mathrm{OW})^{-1}
\end{gathered}
$$

The values of form factor (FF), roundness (RD), aspect ratio (AR), circularity $(\mathrm{C})$, rectangularity $(\mathrm{R})$ and elipticity $(\mathrm{E})$ were calculated and the relationships between otolith length (OL) and shape indices were showed with graphics by using right otolith values. Relationships between fork length and otolith weight, otolith length and otolith width were also evaluated depending on linear regression model.

\section{RESULTS AND DISCUSSION}

A total of $350 \mathrm{~B}$. tauricus were examined as the population consists of $45.5 \%$ females $(n=159), 45.5 \%$ males $(n=159)$ and $9 \%$ undetermined sex (32 juvenile samples) of individuals. The ratio of females to males, in the population, was 1:1. The length and weight distributions of population were $6.5-21.3 \mathrm{~cm}$ and $4.03-122.83 \mathrm{~g}$, respectively. There was no difference between females and males for mean length and weight values ( $t$ test, $\mathrm{P}>0.05$ ).

350 pairs of otolith were measured (Fig. 1). The detailed morphology is documented with scanning electron microscope (SEM) and the distal and proximal surfaces of the otolith were shown in Figure $2 \mathrm{a}$ and $2 \mathrm{~b}$ respectively. The SEM images were firstly shown for asteriscus of $B$. tauricus to determine morphology. The otoliths are very fragile. The general shape of asteriscus otolith of $B$. tauricus is semicircular shape, which has a convex outer face and its margin is moderate serrations and has a well-defined rostrum and antirostrum. Results of this study indicate that Crimean barbel's otolith limits of lobes are clearly identified. Its sulcus acusticus is round and has a curved terminal end (Fig. 2b).

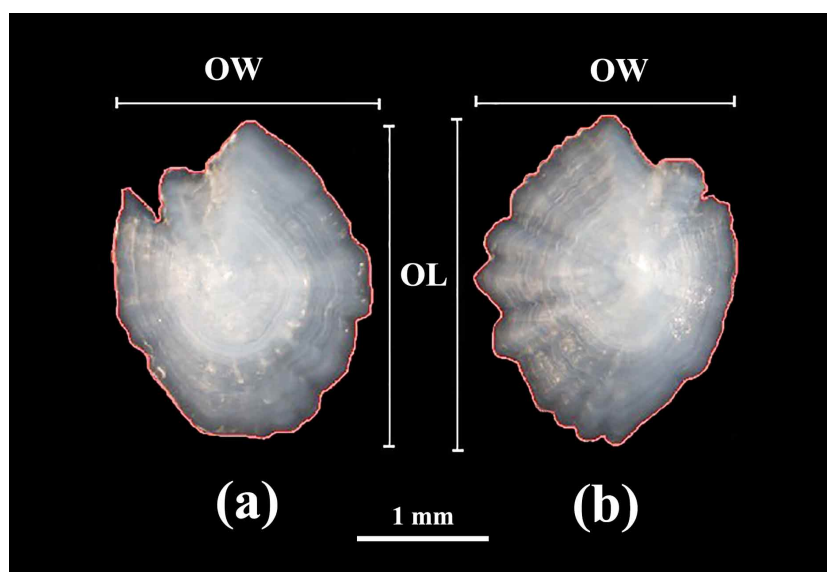

Fig. 1. Length and width measures for otolith pairs on light microscope (a: right; b: left otolith, OL: otolith length; OW: otolith width).

All otolith measurements were given for $B$. tauricus in Table I. For all otolith dimensions, right otolith was bigger, comparing to left ones. The differences were found statistically important $(\mathrm{P}<0.05)$, except the otolith length value. The length of right and left otolith were estimated as $1.918 \mathrm{~mm}$ and $1.903 \mathrm{~mm}$, respectively and the difference was statistically insignificant $(\mathrm{P}>0.05)$ (Table I).

The right and left otolith of females and males were estimated for 318 individuals. The mean of right otolith weight was heavier than the left one value and right one was 


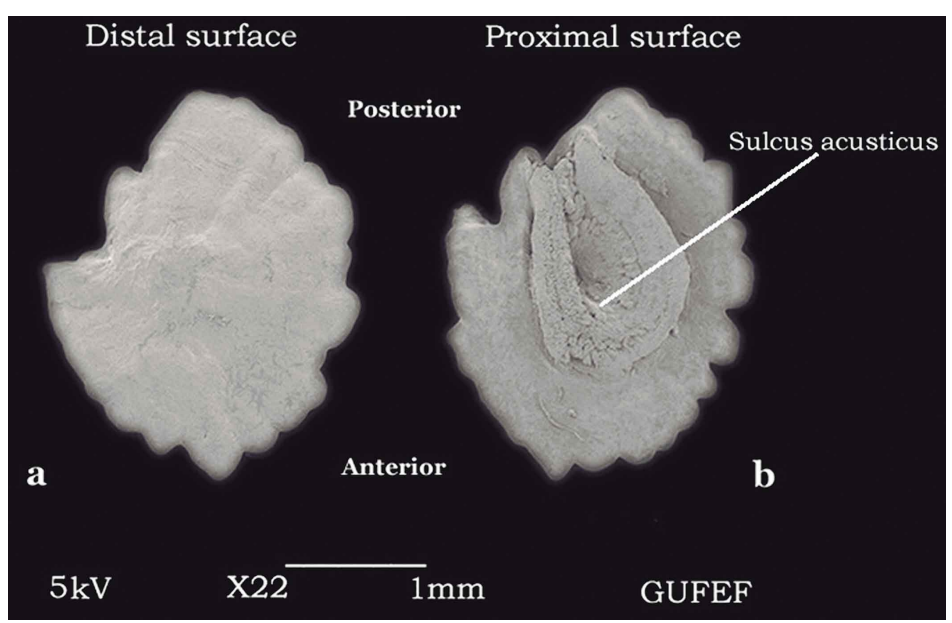

Fig. 2. Image of scanning electron microscope (SEM) of the otolith from Barbus tauricus.

Table I. Results of paired t-test for right and left otolith.

\begin{tabular}{llcccccc}
\hline Variables & Side & Mean & SE & SD & Min & Max & P value \\
\hline \multirow{2}{*}{ Otolith weight } & Left & 0.00063 & 0.000022 & 0.00039 & 0.0001 & 0.0020 & \\
& Right & 0.00069 & 0.000025 & 0.00042 & 0.0001 & 0.0021 & $<0.05$ \\
Otolith length & Left & 1.903 & 0.0157 & 0.2791 & 1.099 & 2.804 & \\
& Right & 1.918 & 0.0167 & 0.2876 & 1.113 & 2.839 & $>0.05$ \\
Otolith width & Left & 1.549 & 0.0119 & 0.2121 & 0.949 & 2.147 & \\
& Right & 1.553 & 0.0120 & 0.2057 & 0.963 & 2.097 & $<0.05$ \\
Otolith area & Left & 2.046 & 0.0313 & 0.5580 & 0.745 & 3.829 & \\
\multirow{3}{*}{ Otolith perimeter } & Right & 2.090 & 0.0333 & 0.5737 & 0.753 & 3.903 & \\
& Left & 5.748 & 0.0491 & 0.8757 & 3.319 & 8.341 & \\
& Right & 5.808 & 0.0523 & 0.9006 & 3.277 & 8.664 & $<0.05$ \\
\hline
\end{tabular}

(SE, standard error; SD, standard deviation).

Table II. The t-test results between females and males for otolith

\begin{tabular}{llcccccc}
\hline Variables & Sex & Mean & SE & SD & Min & Max & P value \\
\hline \multirow{2}{*}{ Left otolith weight } & Female & 0.00072 & 0.000035 & 0.000429 & 0.0001 & 0.0020 & $<0.05$ \\
& Male & 0.00055 & 0.000027 & 0.000325 & 0.0001 & 0.0017 & \\
Right otolith weight & Female & 0.00081 & 0.000039 & 0.000455 & 0.0001 & 0.0021 & $<0.05$ \\
& Male & 0.00059 & 0.000031 & 0.000370 & 0.0001 & 0.0019 & \\
Left otolith length & Female & 1.983 & 0.0239 & 0.2896 & 1.198 & 2.804 & $<0.05$ \\
& Male & 1.869 & 0.0178 & 0.2146 & 1.427 & 2.518 & \\
Right otolith length & Female & 1.996 & 0.0260 & 0.3020 & 1.220 & 2.839 & $<0.05$ \\
& Male & 1.887 & 0.0194 & 0.2297 & 1.363 & 2.525 & \\
Left otolith width & Female & 1.611 & 0.0177 & 0.2140 & 0.992 & 2.147 & $<0.05$ \\
& Male & 1.522 & 0.0143 & 0.1727 & 0.984 & 1.990 & \\
Right otolith width & Female & 1.610 & 0.0180 & 0.2090 & 1.020 & 2.097 & $<0.05$ \\
& Male & 1.528 & 0.0144 & 0.1704 & 1.042 & 1.955 & \\
Left otolith area & Female & 2.207 & 0.0498 & 0.6034 & 0.876 & 3.829 & $<0.05$ \\
Right otolith area & Male & 1.969 & 0.0360 & 0.4333 & 1.054 & 3.407 & \\
& Female & 2.255 & 0.0534 & 0.6199 & 0.889 & 3.903 & $<0.05$ \\
Left otolith perimeter & Male & 2.010 & 0.0386 & 0.4568 & 1.101 & 3.441 & \\
& Female & 6.016 & 0.0757 & 0.9177 & 3.604 & 8.341 & $<0.05$ \\
Right otolith perimeter & Male & 5.628 & 0.0564 & 0.6794 & 4.045 & 7.742 & \\
& Female & 6.066 & 0.0818 & 0.9507 & 3.594 & 8.664 & $<0.05$ \\
& Male & 5.691 & 0.0603 & 0.7136 & 4.123 & 7.674 & \\
\hline
\end{tabular}

(SE, standard error; SD, standard deviation). taller than left one for females and males. While left otolith width was broader than right otolith for females, right otolith of males was larger than left pair. The right otolith weight values were between $0.0001-0.0021 \mathrm{~g}$ and $0.0001-0.0019 \mathrm{~g}$ for females and males, respectively. The left otolith weight values were between $0.0001-0.0020 \mathrm{~g}$ for females and $0.0001-0.0017 \mathrm{~g}$ for males. The area and perimeter values of right and left otolith of females were bigger, comparing to same otolith values of males. These differences between values of females and males were statistically important $(\mathrm{P}<0.05)$ (Table II).

According to paired t-test results, because of important differences between right and left otolith values $(\mathrm{P}<0.05)$, right otolith was used for calculation of form factor, roundness, aspect ratio, circularity, rectangularity and elipticity. The mean values of FF, RD, AR, C, R and E were calculated as $0.769,0.714$, $1.234,16.382,0.690$ and 0.104 , respectively (Table III). FF, RD, AR, C, R and E values were associated with otolith length. When otolith length increased, form factor, roundness and rectangularity values decreased; AR, C and E values increased (Fig. 3).

The relationships of otolith weight, length and width with fork length were determined using right otolith values for all individuals. The best fit was found for the FLOL relationship $\left(\mathrm{r}^{2}=0.80\right)$, while the lowest value of the coefficient of determination was calculated for FL-WO relationship $\left(r^{2}=0.65\right)$ The coefficient of determination value of FL-OW was 0.76 . This value was the lowest both females and males for the FL-WO relationship (0.69 and 0.59 , respectively) (Table IV). Determination of otolith weight is much easier than otolith length and width 

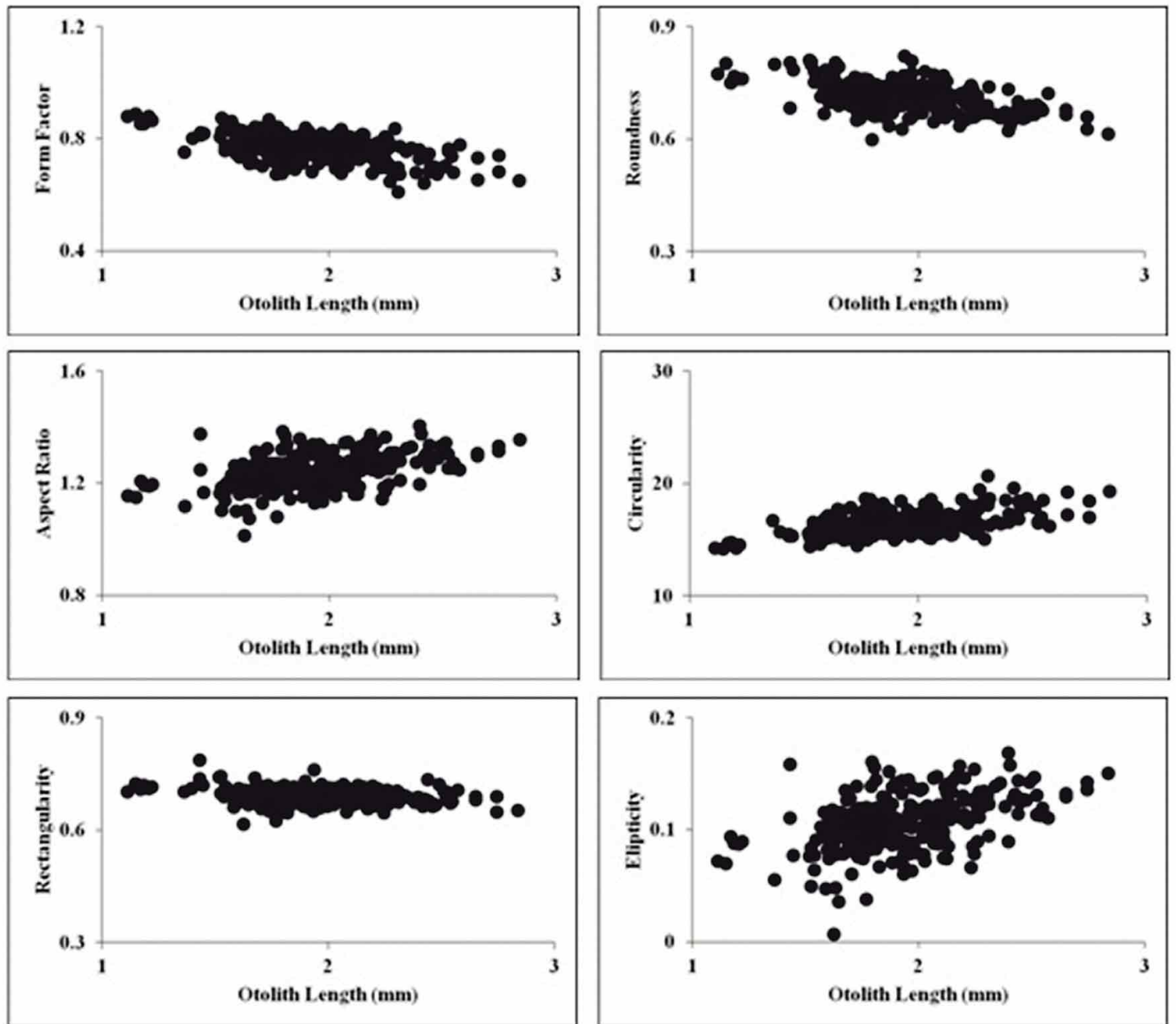

Fig. 3. Relationships between otolith length and shape indices.

Table III. Descriptive statistics of six shape indices (form factor-FF; roundness$\mathrm{RD}$; aspect ratio-AR; circularity-C; rectangularity-R; elipticity-E).

\begin{tabular}{lccccc}
\hline Variables & Mean & SE & SD & Min & Max \\
\hline FF & 0.769 & 0.00267 & 0.04586 & 0.608 & 0.888 \\
RD & 0.714 & 0.00250 & 0.04300 & 0.597 & 1.067 \\
AR & 1.234 & 0.00369 & 0.0635 & 0.848 & 1.405 \\
C & 16.382 & 0.0588 & 1.011 & 14.132 & 20.644 \\
R & 0.690 & 0.00118 & 0.02033 & 0.615 & 0.787 \\
E & 1.740 & 0.0125 & 0.2158 & 1.097 & 2.358
\end{tabular}

\begin{tabular}{lcc}
\hline Relationship & \multicolumn{1}{c}{ Equations } & r2 \\
\hline FL-WO & $\mathrm{WO}=0.0001 \mathrm{FL}-0.0011$ & 0.65 \\
FL-OL & $\mathrm{OL}=0.104 \mathrm{FL}+0.551$ & 0.80 \\
FL-OW & $\mathrm{OW}=0.071 \mathrm{FL}+0.616$ & 0.76 \\
FL-WO (Female) & $\mathrm{WO}=0.0001 \mathrm{FL}-0.001$ & 0.69 \\
FL-OL (Female) & $\mathrm{OL}=0.1 \mathrm{FL}+0.635$ & 0.80 \\
FL-OW (Female) & $\mathrm{OW}=0.0692 \mathrm{FL}+0.672$ & 0.80 \\
FL-WO (Male) & $\mathrm{WO}=0.0001 \mathrm{FL}-0.0011$ & 0.59 \\
FL-OL (Male) & $\mathrm{OL}=0.107 \mathrm{FL}+0.478$ & 0.81 \\
FL-OW (Male) & $\mathrm{OW}=0.0729 \mathrm{FL}+0.570$ & 0.72
\end{tabular}

Table IV. Regression equations between fork length and right otolith variables for all individuals, females and males. WO, otolith weight (g); OL, otolith length (mm); OW, otolith width (mm); FL, fork length $(\mathrm{cm}) ; \mathrm{r}^{2}$, coefficient of determination. 
measurement of process, and a technique often used. There are numerous studies on the subject (Cardinale et al., 2000; Pino et al., 2004; Gümüs et al., 2007; Bostanci, 2009; Bostanci \& Polat, 2011; Keskin, 2013). However, the linear correlation between total length and otolith length can be stronger than the relationship between total length and otolith weight. For instance, FL-WO relationship $\left(r^{2}=0.651\right)$ is lower than FL-OL relationship $\left(r^{2}=0.751\right)$ for Engraulis encrasicolus (Zorica et al., 2010). The similar results were shown for Coris julis (FL-OL $\left.\left(\mathrm{r}^{2}\right)=92.7, \mathrm{FL}-\mathrm{WO}\left(\mathrm{r}^{2}\right)=88.2\right)$, Symphodus tinca $\left(\mathrm{FL}-\mathrm{OL}\left(\mathrm{r}^{2}\right)=86.5\right.$, FL-WO $\left.\left(\mathrm{r}^{2}\right)=80.6\right)$, Symphodus cinereus (FL-OL $\left.\left(\mathrm{r}^{2}\right)=57.3, \mathrm{FL}-\mathrm{WO}\left(\mathrm{r}^{2}\right)=52.4\right)$, Symphodus ocellatus $\left(\mathrm{FL}-\mathrm{OL}\left(\mathrm{r}^{2}\right)=51.6, \mathrm{FL}-\mathrm{WO}\left(\mathrm{r}^{2}\right)=44.7\right)$ (Skeljo \& Ferri, 2012). In addition, similar results for one of the Cyprinid fish Capoeta banarescui, which is a freshwater fish, were shown that the relationship between total length and otolith weight $\left(r^{2}=0.56\right)$ is lower than the other relationships between otolith length $\left(r^{2}=0.88\right)$ and otolith width $\left(r^{2}=0.83\right)$ (Keskin). The current study was shown similarly the relationship between FL-OL $\left(r^{2}=0.80\right)$ is stronger than FL-WO $\left(\mathrm{r}^{2}=0.65\right)$ for $B$. tauricus.

There are many studies that determine the otolith biometry and relationships between fish size (Waessle et al., 2003; Gümüs \& Kurt, 2009; Battaglia et al., 2010; Keskin; Sadighzadeh et al., 2014). Sexual differences in relationships between otolith biometry and fish size were identified in this study, which have been reported for many species (Vallisneri et al., 2008; Bostanci et al., 2012). This differences can be associated to changes in somatic growth between females and males. In addition, it was observed that, in this study for the first time otolith biometrics data from the Cyprinid fish, may be different both the male and female and pair of left and right otolith of the same fish.

KONTAS, S. \& BOSTANCI, D. Caracteristicas morfológicas y biométricas de los otolitos de Barbus tauricus Kessler, 1877 bajo microscopiode luz y electrónico de barrido. Int. J. Morphol., 33(4):1380-1385, 2015.

RESUMEN: Se examinó la morfología de los otolitos, su biometría y la relación entre el tamaño de ellos y la longitud de los peces. Se registró el peso, longitud, grosor, área y perímetro para cada par de otolitos. Se calcularon y se identificaron en los gráficos los valores de factor de forma, redondez, relación de aspecto, circularidad, rectangularidad, elipticidad y las relaciones entre la longitud del otolito y los índices de la forma. De acuerdo con los resultados, la diferencia entre otolitos derechos e izquierdos fue estadísticamente significativo $(\mathrm{P}<0,05)$, excepto la longitud del otolito. Esta es la primera vez que se observa la diferencia de las variables de otolitos, no sólo ente los pares de derecha e izquierda, sino también entre peces hembras y machos. Mientras que el peso de los otolitos tuvo el menor coeficiente de determinación $\left(\mathrm{R}^{2}\right)$, tales como 0,$69 ; 0,59 ; 0,65$, la longitud de los otolitos presentó un $\mathrm{R}^{2}$ más alto: 0,$80 ; 0,81 ; 0.80$, para hembras, machos y todas las muestras, respectivamente. Además, las imágenes de miscroscopía electrónica de barrido son las primeras en mostrar los otolitos de B. tauricus para determinar la morfología de éstos.

PALABRAS CLAVE: Dimensiones de otolitos; Asteriscus; Índices de forma; Miscroscopía electrónica debarrido de otolitos.

\section{REFERENCES}

Assis, C. A. The lagenar otoliths of teleosts: their morphology and its application in species identification, phylogeny and systematics. J. Fish Biol., 62(6):1268-95, 2003.

Battaglia, P.; Malara, D.; Romeo, T. \& Andaloro, F. Relationships between otolith size and fish size in some mesopelagic and bathypelagic species from the Mediterranean Sea (Strait of Messina, Italy). Sci. Mar., 74(3):605-12, 2010.

Bostanci, D. Otolith biometry-body length relationships in four fish species (Chub, Pikeperch, Crucian carp and Common carp). J. Freshw. Ecol., 24(4):619-24, 2009.

Bostanci, D. \& Polat, N. Age and growth of Alburnus tarichi (Güldenstädt, 1814): an endemic fish species of Lake Van (Turkey). J. Appl. Ichthyol., 27(6):1346-9, 2011.

Bostanci, D.; Y1lmaz, S.; Polat, N. \& Kontas, S. The otolith biometry characteristics of black scorpionfish, Scorpaena porcus L., 1758. Black Sea J. Sci., 2:59-68, 2012.
Britton, J. R. \& Shepherd, J. S. Biometric data to facilitate the diet reconstruction of piscivorous fauna. Folia Zool., 54(1-2):193200, 2005.

Campana, S. E. Photographic Atlas of Fish Otoliths of the Northwest Atlantic Ocean. Ontario, NRC Research Press, 2004. pp. 284.

Cardinale, M.; Arrhenius, F. \& Johnson, B. Potential use of otolith weight for the dete83rmination of age-structure of Baltic cod (Gadus morhua) and plaice (Pleuronectes platessa). Fish. Res., 45(3):239-52, 2000.

Chilton, D. E. \& Beamish, R .J. Age determination methods for fishes studied by the groundfish program at the Pacific Biological Station. Ottowa, Canadian Special Publication of Fisheries and Aquatic Sciences, 1982. pp.102.

Das, M. Age determination and longevity in fisheries. Gerontology, 40(2-4):70-96, 1994. 
Gümüs, A.; Bostanc1, D.; Y1lmaz, S. \& Polat, N. Age determination of Scardinius erythrophthalmus (Cyprinidae) inhabiting Bafra fish lakes (Samsun, Turkey) based on otolith readings and marginal increment analysis. Cybium, 31(1):59-66, 2007.

Gümüs, A. \& Kurt, A. Age structure and growth by otolith interpretation of Neogobius melanostomus (Gobiidae) from Southern Black Sea. Cybium, 33(1):29-37, 2009.

Hajkova, P.; Roche, K. \& Kocian, L. On the use of diagnostic bones of brown trout, Salmo trutta m. fario, grayling, Thymallus thymallus and Carpathian sculpin, Cottus poecilopus in Eurasian otter, Lutra lutra diet analysis. Folia Zool., 52(4):38998, 2003.

Keskin, G. Asagı Melet Irmagında (Ordu) Yas,ayan Capoeta banarescui'nun Yas, Büyüme ve Otolit Özellikleri. MSc. Thesis. Ordu, Ordu University, 2013.

Lord, C.; Morat, F.; Lecomte-Finiger, R. \& Keith, P. Otolith shape analysis for three Sicyopterus (Teleostei: Gobioidei: Sicydiinae) species from New Caledonia and Vanuatu. Environ. Biol. Fish., 93(2):209-22, 2012.

Pino, C. A.; Cubillos, L. A.; Araya, M. \& Sepúlveda, A. Otolith weight as an estimator of age in the Patagonian grenadier, Macruronus magellanicus, in central-south Chile. Fish. Res., 66(2-3):145-56, 2004.

Sadighzadeh, Z.; Otero-Ferrer, J. L.; Lombarte, A.; Fatemi, M. R. \& Tuset, V. M. An approach to unraveling the coexistence of snappers (Lutjanidae) using otolith morphology. Sci. Mar., 78(3):353-62, 2014.

Skeljo, F. \& Ferri, J. The use of otolith shape and morphometry for identification and size-estimation of five wrasse species in predator-prey studies. J. Appl. Ichthyol., 28(4):524-30, 2012.

Tuset, V. M.; Lombarte, A. \& Assis, C. A. Otolith atlas for the western Mediterranean, north and central eastern Atlantic. Sci. Mar., 72(Suppl. 1):7-198, 2008.

Tuset, V. M.; Lombarte, A.; González, J. A.; Pertusa, J. F. \& Lorente, M. J. Comparative morphology of the sagittal otolith in Serranus spp. J. Fish Biol., 63(6):1491-504, 2003.

Vallisneri, M.; Trotta, V.; Cavicchi, S. \& Piccinetti, C. Sex-specific somatic-otolith growth relationship in two Gadidae. J. Fish Biol., 72(3):724-30, 2008.

Waessle, J. A.; Lasta, C. A. \& Favero, M. Otolith morphology and body size relationships for juvenile Sciaenidae in the Río de la Plata estuary (35-36º S). Sci. Mar., 67(2):233-40, 2003.

Zorica, B.; Sinovcic, G. \& Kec, V.C. Preliminary data on the study of otolith morphology of five pelagic fish species from the Adriatic Sea (Croatia). Acta Adriat., 51(1):89-96, 2010.

\section{Correspondence to: \\ Prof. Dr. Derya Bostancı \\ Department of Biology \\ Ordu University, \\ Ordu \\ TURKEY}

Email: deryabostanci@gmail.com

Received : 08-04-2015

Accepet: 22-09-2015 